SHORT REPORT

\title{
Serum leptin level in women with idiopathic intracranial hypertension
}

\author{
Y Lampl, Y Eshel, A Kessler, A Fux, R Gilad, M Boaz, Z Matas, M Sadeh
}

J Neurol Neurosurg Psychiatry 2002;72:642-643

Leptin is a protein secreted by adipose cells which influences regulation of energy balance and body weight. Idiopathic intracranial hypertension $(\mathrm{IIH})$ is recognised as a neurological disorder mainly affecting obese females. The aim of this study was to evaluate the association between IIH and serum leptin level in 15 obese patients and compare the results with those for 16 obese and 15 non-obese women. A significantly higher serum leptin level was found in patients with $\mathrm{IIH}$ than in controls $(p<0.0001)$, and this did not correlate with body mass index (BMI). Serum leptin levels were significantly associated with BMI in both control groups $(p<0.0006)$. Additional factors must therefore be involved in the phenomenon of serum leptin increase beyond weight gain. The cause can only be hypothesised, but it seems that the origin is central, probably hypothalamic.

L eptin, a product of the OB gene, is secreted by adipose tissue cells and circulates in plasma. ${ }^{1}$ The circulating plasma leptin is influenced by body weight and food intake and is a regulator of energy balance. ${ }^{23}$ The regulation of energy expenditure is mediated by adiposity signals originating in the hypothalamus. The key role of the hypothalamic endocrine system in regulation of body weight and food intake through serum leptin levels can be interpreted through the adipose tissue-hypothalamus and hypothalamus-adipose tissue endocrine axes. Neuropeptide $\mathrm{Y}^{4-6}$ agouti related peptide, ${ }^{7}$ and melanin concentrating hormone ${ }^{8}$ belong to the group of neuropeptides that affect leptin in the hypothalamic-adipose cell mediated axis, acting by increasing body weight and energy storage. Pro-opiomelanocortin, ${ }^{910}$ corticotropin releasing hormone, ${ }^{11}$ and cocaine amphetamine related transcript ${ }^{12}$ have the opposite effect and act as catabolic peptides. In the transmission of weight states from the periphery to the hypothalamus, leptin has a most important signalling role, ${ }^{11}$ as does insulin. ${ }^{13}{ }^{14}$

The relation between idiopathic intracranial hypertension (IIH) and weight increase has long been disputed. ${ }^{15}{ }^{16}$ Reduction of weight may be of therapeutic benefit. ${ }^{18}{ }^{18} \mathrm{IIH}$ is a neurological disorder mainly of obese females. Examination of obese females with no other neurological complaints or deficits suggests that obesity explains the increase in cerebrospinal pressure in most of the patients with IIH. The increase in intra-abdominal and intrathoracic pressure and raised central venous pressure has been proposed as a cause. However, the relation between the increase in fluid pressure above normal and obesity is controversial ${ }^{15}$ and cannot explain the discrepancy between the very high percentage of obesity in the general population and low incidence of IIH.

To investigate whether patients with IIH have a disturbed leptin function, serum leptin level was measured under food restricted conditions and compared with a group of controls matched for age, sex, and weight.

\section{PATIENTS AND METHODS}

We studied serum leptin levels in women with IIH (group I). The decision to limit the inclusion criteria to women was based on the fact that the relation between IIH and obesity is stronger in women. ${ }^{19}$

Other inclusion criteria were age 18-50 years and completely normal endocrine profile, including cortisol profile, prolactin, follicle stimulating hormone, luteinising hormone, testosterone, androsterone, and thyroid stimulating hormone.

Exclusion criteria were the coexistence of any other neurological, metabolic, or infectious disease or liver or kidney dysfunction and the routine use of any drugs, except acetazolamide (Diamox). Each patient had a brain computed tomography scan; any abnormality was a reason for exclusion.

The blood sample for the single serum leptin measurement was drawn after overnight fasting (last food intake before 2100 ) between 0730 and 0830, at which time blood pressure, height, and weight were measured.

The results were compared with those for two control groups who fulfilled the inclusion and exclusion criteria: group II, obese women (body mass index (BMI) >27.5 $\left.\mathrm{kg} / \mathrm{m}^{2}\right)^{20}$; group III, non-obese women (BMI $>16 \mathrm{~kg} / \mathrm{m}^{2}$ ).

\section{Laboratory analysis}

Blood samples $(10 \mathrm{ml})$ were collected from the antecubital vein into vacutainer tubes (Becton Dickinson) and centrifuged at $1500 \mathrm{~g}$ for 10 minutes. The serum was divided into portions and stored at $-70^{\circ} \mathrm{C}$ until analysed. Leptin was measured with the DSL-23100 kit (Leptin coated-Tube Immunometric Assay Kit; Diagnostic Systems, Webster, Texas, USA).

\section{RESULTS}

Table 1 presents some characteristics of the study population. The duration from first diagnosis of IIH in group I was 16.3 (SD 3.5) months (range 3-9). All patients were treated with acetazolamide ( $750 \mathrm{mg} /$ day). BMI differed significantly by group $(p<0.0001)$. Bonferroni pairwise comparison of means confirmed that groups I and II did not differ from one another in terms of BMI, but that group III had a significantly lower BMI than the other two groups.

As shown in table 1 , mean serum leptin levels differed significantly by group $(\mathrm{p}<0.0001)$. Bonferroni comparison showed that women in group I had significantly higher serum leptin levels than women in group II or group III. The serum leptin levels in groups II and III were only marginally different from one another $(\mathrm{p}=0.02)$.

Linear regression analysis was used to examine association between the variables. No association was detected between age and serum leptin levels. Serum leptin levels were significantly associated with BMI $(p=0.0006)$, such that BMI

Abbreviations: $\mathrm{IH}$, idiopathic intracranial hypertension; $\mathrm{BMI}$, body mass index 
Table 1 Characteristics of the women studied

\begin{tabular}{llll}
\hline & Group I & Group II & Group III \\
\hline Number & 15 & 16 & 15 \\
Age (years) & $28.6(6.4)$ & $34.0(5.5)$ & $29.1(5.7)$ \\
Body mass index & $32.6(4.1)$ & $32.8(3.6)$ & $20.7(4.5)$ \\
Leptin (ng/ml) & $63.7(22.1)$ & $32.9(6.0)$ & $18.4(7.9)$ \\
\hline
\end{tabular}

Values are mean (SD)

Group I, Women with idiopathic intracranial hypertension; group II, obese women; group III, non-obese women.

accounted for about $26 \%$ of the variation in serum leptin levels. This association persisted in groups II and III, but not in group I.

\section{DISCUSSION}

Various studies have found that circulating serum leptin levels are proportional to adipose cell mass, are related to food intake, and reflect energy balance. ${ }^{1-3}$

We found a significant correlation between serum leptin level and BMI in groups II and III. This association did not persist in patients with IIH, suggesting that, in addition to BMI, other factors must contribute to the variation in serum leptin levels. The very high level of leptin found exclusively in women with IIH indicates a link between IIH and leptin. A similar finding of raised serum leptin beyond the expected BMI values has also been shown in patients after hypothalamic surgery. Brabant et $a l^{21}$ showed a significantly higher blood level of leptin after craniopharyngeal removal. In about $40 \%$ of the patients, serum leptin levels were higher than expected for their BMI as compared with the sample taken before surgery. The weight gain corresponded to the increase in leptin level in only about $50 \%$ of patients. There were no similar findings in patients who had received nonhypothalamic surgery or in healthy controls.

The relation between defective weight regulation and high circulating leptin level is seen in the $\mathrm{db} / \mathrm{db}$ mouse and $\mathrm{fa} / \mathrm{fa}$ Zucker rat. $22-24$ Dysfunction of the leptin receptor in the hypothalamus with overexpression of the ob gene and increased circulating leptin is probably caused by a polymorphism of the leptin receptors. ${ }^{125}$ This was also assumed to be the case in patients with severe early onset of obesity. ${ }^{26} \mathrm{Clem}$ ent $e t a^{27}$ reported an association between mutation of a human leptin receptor and severe obesity and pituitary dysfunction. A failure in the transport of leptin from the cerebrospinal fluid into the brain ${ }^{28}$ and desensitisation of the hypothalamic structures ${ }^{29}$ were proposed as mechanisms of this phenomenon.

In conclusion, severe obesity in the presence of significantly raised circulating leptin levels was found to be present in women with IIH and may have a central origin, probably hypothalamic dysfunction. Further studies are needed to clarify and ascertain the exact mechanism of these disturbances.

\section{ACKNOWLEDGEMENTS}

We extend our appreciation to Ms Judy Brandt for her skilful English editing and word processing expertise and contributions.

\section{Authors' affiliations}

Y Lampl*, Y Eshel*, R Gilad*, M Sadeh*, Department of Neurology, E Wolfson Medical Center, Holon, Israel

A Kessler*, Neurology Department, Meir Hospital, Kfar Sava, Israel
A Fux*, Z Matas, Biochemical Laboratory, E Wolfson Medical Center M Boaz, Biostatistical Unit, E Wolfson Medical Center

*Affiliated with the Sackler Faculty of Medicine, Tel Aviv University, Israel

Correspondence to: Dr Lampl, Department of Neurology, Edith Wolfson Medical Center, Holon 58100, Israel.

Received 29 August 2001

In revised form 6 December 2001

Accepted 14 December 2001

\section{REFERENCES}

1 Zhang $Y$, Proenca R, Maffei $M$, et al. Positional cloning of the mouse obese gene and its human homologue. Nature 1994;37:425-32.

2 Maffei M, Halaas J, Ravussin E, et al. Leptin levels in human and rodent: measurement of plasma leptin and ob RNA in obese and weight-reduced subjects. Nature 1995;1:1155-61.

3 Frederich RC, Hamann A, Anderson S, et al. Leptin levels reflect body lipid content in mice: evidence for diet-induced resistance to leptin action. Nat Med 1995;1:1311-04

4 Schwartz NW, Seeley RJ, Campfield LA, et al. Identification of targets of leptin actin in rat hypothalamus. J Clin Invest 1996:98:1101-6.

5 Schwartz NW, Erickson JC, Baskin DG, et al. Effect of fasting and leptin deficiency on hypothalamic neuropeptide $Y$ gene transcription in vivo revealed by expression of a lacZ reporter gene. Endocrinology 1998;139:2623-35.

6 Stanley BG, Magdalin W, Leibowitz SF. Evidence that neuropeptide Y elicits eating by acting in the caudolateral paraventricular/perifornical hypothalamus. Ann NY Acad Sci 1990;611:489-90.

7 Shutter YR, Graham M, Kinsey AC, et al. Hypothalamic expression of ART, a novel gene related to agouti, is up-regulated in obese and diabetic mutant mice. Genes Dev 1997;11:593-602.

8 Qu DQ, Ludwig DS, Gammeltoft S, et al. A role for melanin-concentrating hormone in the central regulation of feeding behaviour. Nature 1996;380:243-7.

9 Thornton JE, Cheung CC, Clifton DK, et al. Regulation of hypothalamic proopiomelanocortin mRNA by leptin in ob/ob mice. Endocrinology 1997: 138:5063-6.

10 Schwartz MW, Seeley R, Woods SC, et al. Leptin increases hypothalamic pro-opiomelanocortin mRNA expression in the rostral arcuate nucleus. Diabetes 1997;46:2119-23.

11 Schwartz MW, Seeley RJ. Neuroendocrine responses to starvation and weight loss. N Engl J Med 1997;336:1802-11.

12 Kristensen $\mathbf{P}$, Judge ME, Thim $L$, et al. Hypothalamic CART is a new anorectic peptide regulated by leptin. Nature 1998;393:72-6.

13 Woods SC, Seeley RJ, Porte D Jr, et al. Signals that regulate food intake and energy homeostasis. Science 1998;280:1378-83.

14 Schwartz MW, Figlewicz DP, Baskin DP, et al. Insulin in the brain: a hormonal regulator of energy balance. Endocr Rev 1992;13:387-414

15 Corbett JJ, Mehta MP. Cerebrospinal fluid pressure in normal obese subjects and patients with pseudotumor. Neurology 1983;33:1386-8.

16 Givseffi V, Wall M, Siegel PZ, et al. Symptoms and disease associations in idiopathic intracranial hypertension: a case control study. Neurology 1991:41:239-44.

17 Kupersmith MJ, Gamell L, Turbin R, et al. Effects of weight loss on the course of idiopathic intracranial hypertension in women. Neurology 19 98;50:1094-8

18 Johnson LN, Krohel GB, Madsen RW, et al. The role of weight loss and acetazolamide in the treatment of idiopathic intracranial hypertension (pseudotumor cerebri). Ophthalmology 1998;105:2313-17.

19 Durcan FJ, Corbett JJ, Wall M. The incidence of pseudotumor cerebri population studies in lowa and Louisiana. Arch Neurol 1988;45:875-77

20 NIH Technology Assessment Conference Panel. Methods for voluntary weight loss and control. Ann Intern Med 1992;1 16:942-6.

21 Brabant G, Horn R, Mayr B, et al. Serum leptin levels following hypothalamic surgery. Horm Metab Res 1996:28;728-31.

22 Chen $\mathrm{H}$, Charlat O, Tartaglia LA, et al. Evidence that the diabetes gene encodes the leptin receptor: identification of a mutation in the leptin receptor gene in db/db mice. Cell 1996;84:491-5

23 Phillips MS, Liu QY, Hammond HA, et al. Leptin receptor missense mutation in the fatty Zucker rat. Nature Genet 1996;13:18-19.

24 Yamashita T, Murakami T, Lida M, et al. Leptin receptor of Zucker fatty rat performs reduced signal transduction. Diabetes 1997:46:1077-80.

25 Lee GH, Proenca R, Montez JM, et al. Abnormal splicing of the leptin receptor in diabetic mice. Nature 1996;379:632-5

26 Montague CT, Farooqi IS, Whitehead JP, et al. Congenital leptin deficiency is associated with severe early-onset obesity in humans. Nature 1997:387:903-8.

27 Clement K, Vaisse C, Lahlou N, et al. A mutation in the human leptin receptor gene causes obesity and pituitary dysfunction. Nature 1998;392:398-401.

28 Banks WA, Kastin AJ, Huang WT, et al. Leptin enters the brain by a saturable system independent of insulin. Peptides 1996;17:305-11.

29 Huang XF, Lin S, Zhang R. Upregulation of leptin receptor mRNA expression in obese mouse brain. Neuroreport 1997;8:1035-8. 